MARINADE Vol. 01(01) : $45-55$ (Oktober 2018)

e-ISSN : 2654-4415

online : http://ojs.umrah.ac.id/index.php/marinade

\title{
PENDUGAAN UMUR SIMPAN SERBUK MINUMAN FUNGSIONAL LINTAH LAUT (Discodoris sp.) DENGAN METODE ACCELERATED SHELF LIFE TEST (ASLT): MODEL ARRHENIUS
}

\section{Estimated Shelf Life Beverage Powders Sea Slug (Discodoris sp.) with Accelerated} Shelf Life Test (ASLT) Method: Arrhenius Model

\author{
R. Marwita Sari Putri ${ }^{\left.{ }^{*}\right)}$, Nurjanah ${ }^{2)}$, Kustiariyah Tarman ${ }^{2)}$ \\ 1) Program Studi Teknologi Hasil Perikanan, Fakultas IImu Kelautan dan Perikanan, Universitas \\ Maritim Raja Ali Haji. \\ ${ }^{2)}$ Departemen Teknologi Hasil Perairan, Fakultas Perikanan dan IImu Kelautan, Institut \\ Pertanian Bogor
}

*Korespondensi : wita@umrah.ac.id

Diterima April 2018; Disetujui Juli 2018

\begin{abstract}
The Arrhenius model ASLT method is widely used to estimate the shelf life of food products that are easily damaged by the effects of chemical reactions, including fat oxidation, Maillard reactions, protein denaturation and so on. The aim of this study was to determine the best shelf life through stability testing. Testing shelf life was done by acceleration time or acceleration model using Arrhenius method. During the storage period, the product was stored in three different temperature conditions, ie, $30^{\circ} \mathrm{C}, 35^{\circ} \mathrm{C}$ and $45^{\circ} \mathrm{C}$. Stability test performed on every 7 days observation of water content test $\left(a_{w}\right)$. Estimation of shelf life based on the critical parameter that is water activity value $\left(a_{w}\right)$ hence can be known save age of functional beverage powders sea slug of T2 have a longer shelf life when compared with $T 1$.
\end{abstract}

Keywords : Discodoris sp, ASLT method, arrhenius, water activity

\begin{abstract}
ABSTRAK
Metode ASLT model Arrhenius banyak digunakan untuk pendugaan umur simpan produk pangan yang mudah rusak oleh akibat reaksi kimia, antara lain oksidasi lemak, reaksi Maillard, denaturasi protein dan sebagainya. Tujuan dari penelitian ini adalah menentukan masa simpan terbaik melalui pengujian stabilitas. Pengujian masa simpan dilakukan dengan percepatan waktu atau model akselerasi menggunakan metode Arrhenius. Selama masa penyimpanan, produk disimpan pada tiga kondisi suhu yang berbeda, yaitu suhu $30{ }^{\circ} \mathrm{C}, 35^{\circ} \mathrm{C}$ dan $45^{\circ} \mathrm{C}$. Uji stabilitas yang dilakukan pada setiap 7 hari pengamatan uji kadar air $\left(\mathrm{a}_{\mathrm{w}}\right)$ terhadap hari ke-0 dan hari ke-60 penyimpanan. pendugaan umur simpan berdasarkan parameter kritis yaitu nilai water activity $\left(\mathrm{a}_{\mathrm{w}}\right)$ maka dapat diketahui umur simpan formula serbuk minuman dengan formula T2 memiliki umur simpan yang lebih lama bila dibandingkan dengan formula T1.
\end{abstract}

Kata kunci :Discodoris sp, metode ASLT, arrhenius, water activity 


\section{PENDAHULUAN}

Serbuk minuman fungsional lintah laut (Discodoris sp.) merupakan produk inovasi dari lintah laut sebagai bahan utama dan menggunakan bahan-bahan tambahan yaitu, ekstrak dari temulawak (Curcuma xanthorriza Roxb.), ekstrak jeruk lemon (Citrus medical var. Lemon), ekstrak jahe merah (Zingiber officinalle Rosc), karaginan, maltodekstrin dan sukrosa. Minuman fungsional ini berbentuk serbuk dengan metode pengolahan yang menggunakan pengering semprot (spray Dryer).

Bagi semua produk, untuk memperoleh penerimaan dari konsumen maka kandungan nutrisi serta kualitasnya harus tetap konsisten mulai dari waktu proses, penyimpanan dan distribusi sampai saatnya produk dikonsumsi. Selama ini industri farmasi dan makanan telah memiliki pedoman penentuan stabilitas produk dengan jaminan label, tetapi tidak demikian bagi nutraceutical, pangan fungsional maupun food supplement atau makanan tambahan. Untuk menjaga atau mempertahankan penerimaan konsumen dan menghindari tuntutan pemerintah dan undang-undang, maka baik nutraceutical, pangan fungsional maupun makanan tambahan juga harus dievaluasi stabilitasnya termasuk penentuan daya tahan produk serta jaminan keakuratan seperti yang tercantum pada label. Manfaat fisiologis yang dicapai adalah produk tersebut dikonsumsi dan komponen bioaktif tetap ada pada konsentrasi yang dibutuhkan. Jika kondisi ini tidak tercapai maka nutraceutical maupun pangan fungsional kehilangan khasiatnya (Shi 2007).
Pertumbuhan mikroba dalam produk dapat menurunkan sensori penerimaannya melalui kerusakan atau menimbulkan resiko kesehatan. Perubahan fisik antara lain pengerasan pada buah kering dan melembutnya sereal merupakan mekanisme lain dari hilangnya daya tahan produk. Akhirnya reaksi kimia dapat terjadi selama pengolahan dan penyimpanan menghasilkan perubahan-perubahan, yakni tidak diterimanya perubahan warna, hilangnya nutrisi dan perubahan rasa selama penyimpanan dan distribusi. Produk pangan akan mengalami kehilangan bobot, nilai pangan, mutu, nilai uang, daya tumbuh dan kepercayaan (Rahayu et al. 2003).

Salah satu produk yang dapat kehilangan daya tahannya adalah minuman serbuk lintah laut (Discodoris $\mathrm{sp}$ ). Metode ASLT model Arrhenius banyak digunakan untuk pendugaan umur simpan produk pangan yang mudah rusak oleh akibat reaksi kimia, antara lain oksidasi lemak, reaksi Maillard, denaturasi protein dan sebagainya. Metode Accelerated Shelf Life Test (ASLT) Model Arrhenius merupakan metode pendugaan umur simpan produk dengan menggunakan suhu akselerasi sehingga dapat mempercepat reaksi yang menyebabkan kerusakan pada produk (Hasany et al. 2017). Metode Accelerated Shelf Life Test (ASLT) Model Arrhenius pada umumnya diaplikasikan pada semua jenis produk pangan khususnya pada produk yang mengalami penurunan kualitas akibat efek deteriorasi kimiawi (Arpah 2007). 


\section{BAHAN DAN METODE}

\section{Bahan dan Alat}

Bahan baku lintah laut (Discodoris sp.) yang digunakan dalam penelitian ini diperoleh dari perairan Cirebon, Jawa Barat. Bahan-bahan tambahan untuk formulasi meliputi jahe, temulawak, jeruk lemon dalam keadaan segar dan maltodekstrin.

Alat-alat yang digunakan untuk analisis adalah inkubator, autoklaf, HPLC merek waters coorporation USA, spektrofotometer merek Hitachi U-2800 model UV-VIS RIS UV 2500, AAS Model Varian AA-30 Lampu katoda Pb, $\mathrm{Cd}$, As, $\mathrm{Hg}, \mathrm{Cu}$, spray dryer, neraca analitik, $\mathrm{pH}$ meter Orion Benchinp model $410 \mathrm{~A}$, tanur, seperangkat alat soxhlet, labu Kjeldahl, pipet mohr $5 \mathrm{~mL}$ dan $10 \mathrm{~mL}$, labu takar $50 \mathrm{~mL}, 100 \mathrm{~mL}$, $500 \mathrm{~mL}$ dan $1000 \mathrm{~mL}$, corong labu semprot dan alat-alat gelas.

\section{Tahap formulasi serbuk minuman fungsional Discodoris sp. (Putri et al. 2013)}

Lintah laut (Discodoris sp.) diambil di perairan Cirebon dalam keadaan hidup kemudian langsung dipreparasi. Lintah laut dicuci sampai bersih dengan air tawar kemudian dikeluarkan jeroannya. Daging lintah laut kemudian diblender selama 10-30' menjadi ukuran yang lebih kecil dengan penambahan air 1:1 (b/v). Kemudian dilakukan pemasakan dengan suhu $90^{\circ} \mathrm{C}$ selama 8-10 menit. Kemudian sampel disaring menggunakan kain blacu untuk diambil ekstraknya.

Jahe segar dikupas kulitnya dan dicuci dengan air tawar kemudian diblender selama 10-20 menit menjadi ukuran yang lebih kecil dengan penambahan air 1:1 (b/v), sampel disaring menggunakan kain blacu untuk diambil ekstraknya. Kemudian dilakukan pemasakan dengan suhu $90^{\circ} \mathrm{C}$ selama 6-10 menit. Penambahan ekstrak jahe dimaksudkan untuk menghilangkan bau amis yang berasal dari lintah laut (Discodoris sp.).

Temulawak segar dikupas kulitnya dan dicuci dengan air tawar kemudian diblender selama 10-20 menit menjadi ukuran yang lebih kecil dengan penambahan air 1:1 (b/v), sampel disaring menggunakan kain blacu untuk diambil ekstraknya. Kemudian dilakukan pemasakan dengan suhu $90^{\circ} \mathrm{C}$ selama 6-10 menit.

Jeruk lemon segar diperas selanjutnya air hasil perasannya diambil dan ditambahkan air 1:1 (b/v), kemudian baru didapat ekstrak jeruk lemon segar. Bahan utama dan bahan tambahan dicampur sesuai dengan formulasi kemudian dilakukan penambahan maltodekstrin sebanyak $10 \%$ dari berat larutan minuman fungsional yang dimasukkan pada saat proses spray dilakukan. Setelah minuman dalam bentuk serbuk baru dilakukan penambahan sukrosa $(1: 1(\mathrm{~b} / \mathrm{b}))$ dan karaginan rumput laut (1\%). Pada Tabel 1 disajikan formulasi serbuk minuman Discodoris sp.

\section{Pengukuran aktivitas air $\left(a_{w}\right)$}

Aktivitas air diukur dengan Shibaura $a_{w}$ meter WA-360. Sebelum digunakan alat dikalibrasi terlebih dahulu sebelum penggunaan dengan menggunakan aw garam standar. Standar $\mathrm{a}_{\mathrm{w}} \mathrm{NaCl}$ adalah 0,7509 dan $\mathrm{K}_{2} \mathrm{SO}_{4}$ adalah $0,97\left(30{ }^{\circ} \mathrm{C}\right)$. Setelah kalibrasi selesai, bahan dengan berat 5 gram dimasukkan ke dalam $a_{w}$ meter selama kurang lebih 30 menit. Selanjutnya dibaca skala pada $a_{w}$ meter. 
Tabel 1. Formulasi serbuk minuman fungsional Discodoris sp.

\begin{tabular}{ccccc}
\hline Formula & Bahan utama (\%) & \multicolumn{3}{c}{ Bahan-bahan pembantu (\%) } \\
\hline & Discodoris sp. & Jahe & Temulawak & Jeruk lemon \\
T1. & 20 & 40 & 20 & 20 \\
T2. & 25 & 40 & 15 & 20 \\
\hline
\end{tabular}

\section{Pendugaan umur simpan dengan metode ASLT}

Model Arrhenius dilakukan dengan menyimpan produk pangan dengan kemasan akhir pada minimal tiga suhu penyimpanan ekstrim. Hasil pengamatan bagi setiap parameter dihitung laju penurunan mutunya per 7 hari dengan menggunakan plot Arhenius dalam grafik hubungan antara nilai Ink apabila mengikuti ordo reaksi satu, dan Ink nol apabila mengikuti ordo reaksi nol sebagai sumbu y dan sebagai sumbu $x$ nya adalah suhu pada masing-masing penyimpanan $\left(30^{\circ} \mathrm{C}\right.$, $35^{\circ} \mathrm{C}$ dan $45^{\circ} \mathrm{C}$ ).

Kemudian dicari nilai In $\mathrm{k}$ atau nilai konstanta penurunan mutu per hari yang diperoleh dari kemiringan persamaan regresi grafik masingmasing suhu penyimpanan tersebut. Setelah nilai Ink diperoleh, kemudian dicari nilai $k$ untuk masing-masing suhu penyimpanan. Nilai $k$ merupakan gradien dari regresi linier yang didapat dari ketiga suhu penyimpanan. Dari regresi linier yang diperoleh pada kurva arrhenius ini dapat diprediksi umur simpan produk dengan menggunakan rumus:

$$
\mathrm{k}=\mathrm{k}_{0} \mathrm{e}^{-\mathrm{E} / \mathrm{RT}}
$$

Keterangan :

$\mathrm{k}=$ konstanta penurunan mutu

$\mathrm{k}_{0}=$ konstanta (tidak tergantung suhu)

$\mathrm{Ea}=$ energi aktivasi

$\mathrm{T}=$ suhu mutlak $(\mathrm{K})$

$\mathrm{R}=$ konstanta gas $(1,986 \mathrm{kal} / \mathrm{mol} \mathrm{K})$
Dengan mengubah persamaan menjadi:

$$
\ln k=\ln k_{0}+(-E a / R) 1 / T
$$

Dimana, $k_{0}$ merupakan konstanta penurunan mutu produk yang tidak tergantung pada suhu, sedangkan $k$ merupakan konstanta penurunan mutu dari salah satu kondisi suhu yang digunakan $\left(30^{\circ} \mathrm{C}, 35^{\circ} \mathrm{C}, 45^{\circ} \mathrm{C}\right)$ dan $\mathrm{Ea} / \mathrm{R}$ merupakan gradien yang diperoleh dari plot Arrhenius. Dengan perhitungan menggunakan rumus ini, akan diperoleh nilai Ko. Umur simpan menurut ordo reaksi satu diperoleh dengan rumus :

$$
t=\frac{\ln A o-\ln A t}{\text { Ko }}
$$

Keterangan :

$\mathrm{t}=$ prediksi umur simpan (hari)

Ao = nilai mutu awal

At $=$ nilai mutu produk yang tersisa setelah waktu $\mathrm{t}$

$\mathrm{Ko}=$ konstanta

Dari rumus di atas dapat diprediksi umur simpan dalam hari atau bulan. Sedangkan apabila mengikuti ordo reaksi nol umur simpan dapat diperoleh dengan menggunakan rumus:

$$
t=\frac{\text { Ao-At }}{\text { Ko }}
$$

Selama masa penyimpanan, produk disimpan pada tiga kondisi suhu yang berbeda, yaitu suhu $30^{\circ} \mathrm{C}$, suhu $35{ }^{\circ} \mathrm{C}$ dan suhu $45{ }^{\circ} \mathrm{C}$. Frekuensi pengamatan dilakukan 7 hari sekali 
pada masing-masing suhu selama 60 hari.

\section{Analisis Data}

Data pengamatan dari uji stabilitas dianalisis menggunakan teknik regresi linier, dan dibantu dengan metode Arrhenius untuk menduga umur simpan produk (Arpah 2001). Model Arrhenius adalah:

$$
k=k_{0} e^{-E / R T}
$$

Keterangan:

$\mathrm{k}=$ konstanta penurunan mutu

$\mathrm{k}_{0}=$ konstanta (tidak bergantung pada suhu)

$E$ = energi aktivasi

$\mathrm{R}=$ konstanta gas $1,986 \mathrm{kal} / \mathrm{mol}$

\section{HASIL DAN PEMBAHASAN}

Penurunan mutu makanan dapat diketahui dari perubahan faktor mutu, oleh karenanya dalam menentukan daya simpan suatu produk perlu dilakukan pengukuran terhadap atribut mutu produk. Menurut Floros (1993) umur simpan adalah waktu yang diperlukan produk pangan dalam suatu kondisi penyimpanan untuk sampai pada tingkatan degradasi mutu tertentu. Hasil berbagai reaksi kimiawi yang terjadi di dalam produk makanan bersifat akumulatif dan irreversible (tidak dapat dipulihkan kembali) selama penyimpanan sehingga pada saat tertentu mengakibatkan mutu makanan tidak dapat diterima lagi.

Tabel 2. Water activity $\left(\mathrm{a}_{\mathrm{w}}\right)$ formula T1 minuman fungsional lintah laut (Discodoris sp.) selama penyimpanan dengan tiga suhu yang berbeda

\begin{tabular}{cccccc}
\hline \multicolumn{2}{c}{ Suhu $30^{\circ} \mathrm{C}$} & \multicolumn{2}{c}{ Suhu $35^{\circ} \mathrm{C}$} & \multicolumn{2}{c}{ Suhu $45^{\circ} \mathrm{C}$} \\
\hline Hari & $\mathrm{a}_{\mathrm{w}}$ & Hari & $\mathrm{a}_{\mathrm{w}}$ & Hari & $\mathrm{a}_{\mathrm{w}}$ \\
\hline 7 & 0,50 & 7 & 0,50 & 7 & 0,52 \\
14 & 0,54 & 14 & 0,54 & 14 & 0,53 \\
21 & 0,54 & 21 & 0,55 & 21 & 0,53 \\
28 & 0,54 & 28 & 0,55 & 28 & 0,54 \\
35 & 0,57 & 35 & 0,57 & 35 & 0,54 \\
42 & 0,57 & 42 & 0,57 & 42 & 0,55 \\
49 & 0,57 & 49 & 0,58 & 49 & 0,55 \\
56 & 0,60 & 56 & 0,60 & 56 & 0,56 \\
60 & 0,60 & 60 & 0,60 & 60 & 0,58 \\
\hline
\end{tabular}

Tabel 3. Water activity $\left(\mathrm{a}_{\mathrm{w}}\right)$ formula T2 minuman fungsional lintah laut (Discodoris sp.) selama penyimpanan dengan tiga suhu yang berbeda

\begin{tabular}{cccccc}
\hline \multicolumn{2}{c}{ Suhu $30^{\circ} \mathrm{C}$} & \multicolumn{2}{c}{ Suhu $35^{\circ} \mathrm{C}$} & \multicolumn{2}{c}{ Suhu $45^{\circ} \mathrm{C}$} \\
\hline Hari & $\mathrm{a}_{\mathrm{w}}$ & Hari & $\mathrm{a}_{\mathrm{w}}$ & Hari & $\mathrm{a}_{\mathrm{w}}$ \\
\hline 7 & 0,44 & 7 & 0,46 & 7 & 0,45 \\
14 & 0,44 & 14 & 0,48 & 14 & 0,49 \\
21 & 0,50 & 21 & 0,50 & 21 & 0,49 \\
28 & 0,54 & 28 & 0,52 & 28 & 0,49 \\
35 & 0,54 & 35 & 0,53 & 35 & 0,50 \\
42 & 0,54 & 42 & 0,53 & 42 & 0,53 \\
49 & 0,54 & 49 & 0,53 & 49 & 0,54 \\
56 & 0,55 & 56 & 0,54 & 56 & 0,55 \\
60 & 0,56 & 60 & 0,55 & 60 & 0,55 \\
\hline
\end{tabular}


Pada penelitian ini parameter kritis yang digunakan adalah aktivitas air. Pemilihan parameter aktivitas air karena makanan kering termasuk minuman serbuk ini pada umummya mengalami kerusakan apabila menyerap uap air berlebihan. Kerusakan akibat air ini cukup kompleks karena dapat melibatkan berbagai jenis reaksi kerusakan yang sensitif terhadap perubahan $a_{w}$. Beberapa reaksi dapat berlangsung secara spontan yaitu reaksi Maillard, kehilangan atau kerusakan vitamin, oksidasi lipida, dan reaksi pembentukan off-flavor. Semua organisme membutuhkan air untuk kehidupan. Air berperan dalam proses metabolisme sel dalam bentuk cair, apabila air tersebut mengalami kristalisasi dan es atau terikat dalam larutan gula atau garam, maka air tidak dapat digunakan oleh sel mikroba. Jumlah air dalam bahan pangan disebut sebagai aktivitas air.

Kandungan aktivitas air dalam makanan dideskripsikan sebagai "batasan" kandungan air dalam makanan yang dapat diukur, yaitu keberadaannya sebagai cairan banyak berperan pada saat terjadinya reaksi kimia dan biokimia yang ada dalam suatu bahan (Barbosa-Cánovas et al.
2007). Nilai $a_{w}$ yang rendah berpengaruh terhadap jumlah mikroba pada bahan pangan. Nilai $a_{w}$ yang rendah berarti jumlah air yang dapat dimanfaatkan oleh mikroba untuk tumbuh pada bahan pangan tersebut sedikit sehingga akan menghambat pertumbuhan mikroba. Bakteri umumnya tumbuh dan berkembang baik hanya dalam media dengan nilai $a_{w}$ tinggi $(0,91)$, khamir membutuhkan nilai $a_{w}$ lebih rendah $(0,87-0,91)$ dan kapang lebih rendah lagi yaitu $(0,80-$ 0,87) (Buckle et al. 1987). Mikroba hanya dapat tumbuh pada kisaran $a_{w}$ tertentu oleh karena itu untuk mencegah pertumbuhan mikroba, nilai $\mathrm{a}_{\mathrm{w}}$ bahan pangan harus diatur. Pada Tabel 2 dan 3 dapat disajikan bahwa semakin lama penyimpanan maka $a_{w}$ minuman fungsional lintah laut ini cendrung semakin meningkat. Nilai $a_{w}$ formula minuman serbuk $\mathrm{T} 1$ berkisar antara 0,50-0,60. Formula minuman $\mathrm{T} 1$ pada 0 hari penyimpanan sudah menunjukkan nilai $a_{w}$ yang tinggi yaitu 0,50 hal ini berbeda dengan formula minuman T2 pada 0 hari penyimpanan yaitu 0,44 . Tingginya nilai $a_{w}$ pada formula T1 dari pada formula T2 akan mempengaruhi jumlah mikroba yang tumbuh.

Tabel 4. Nilai koefisien korelasi (R2) pada perhitungan pendugaan umur simpan minuman fungsional lintah laut formula T1 berdasarkan parameter water $\operatorname{activity}\left(\mathrm{a}_{\mathrm{w}}\right)$

\begin{tabular}{cccccc}
\hline \multicolumn{2}{c}{\begin{tabular}{c} 
Suhu \\
\multicolumn{2}{c}{ Penyimpanan }
\end{tabular}} & $\begin{array}{c}1 / \mathrm{T} \\
(1 / \mathrm{K})\end{array}$ & $\mathrm{R}^{2}$ & $\mathrm{~K}$ & $\mathrm{Ln} \mathrm{K}$ \\
\cline { 1 - 1 } \cline { 5 - 6 }${ }^{\circ} \mathrm{C}$ & $\mathrm{K}$ & & $\begin{array}{c}\text { Ordo } \\
\text { satu }\end{array}$ & $\begin{array}{c}\text { Ordo } \\
\text { satu }\end{array}$ & Ordo satu \\
\hline 30 & 303 & 0,0033 & 0,8941 & 0,0194 & $-3,9425$ \\
35 & 308 & 0,0033 & 0,8835 & 0,0195 & $-3,9373$ \\
45 & 318 & 0,0031 & 0,9505 & 0,0105 & $-4,5564$ \\
\hline
\end{tabular}


Tabel 5. Nilai koefisien korelasi (R2) pada perhitungan pendugaan umur simpan minuman fungsional lintah laut formula T2 berdasarkan parameter water activity $\left(\mathrm{a}_{\mathrm{w}}\right)$

\begin{tabular}{|c|c|c|c|c|c|}
\hline \multicolumn{2}{|c|}{$\begin{array}{c}\text { Suhu } \\
\text { Penyimpanan }\end{array}$} & \multirow[t]{2}{*}{$\begin{array}{c}1 / \mathrm{T} \\
(1 / \mathrm{K})\end{array}$} & \multicolumn{2}{|l|}{$\mathrm{R}^{2}$} & Ln K \\
\hline${ }^{\circ} \mathrm{C}$ & $\mathrm{K}$ & & $\begin{array}{l}\text { Ordo } \\
\text { satu }\end{array}$ & $\begin{array}{l}\text { Ordo } \\
\text { satu }\end{array}$ & Ordo satu \\
\hline 30 & 303 & 0,0033 & 0,7841 & 0,0044 & $-5,4262$ \\
\hline 35 & 308 & 0,0033 & 0,8734 & 0,0031 & $-5,7764$ \\
\hline 45 & 318 & 0,0031 & 0,9125 & 0,0035 & $-5,6550$ \\
\hline
\end{tabular}

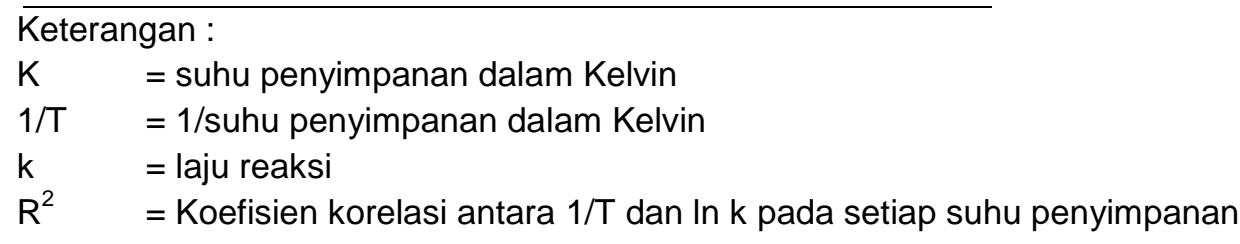

Menurut Herawati (2008) aktivitas air $\left(\mathrm{a}_{\mathrm{w}}\right)$ berkaitan erat dengan kadar air bahan pangan. Menurut Labuza (1982) makanan kering yang dikemas akan kehilangan kerenyahan ketika nilai $a_{w}$ berkisar antara 0,35-0,5 dan dikatakan tidak aman untuk dikonsumsi pada selang $a_{w} \quad 0,7-0,75$. Diatas selang tersebut mikroorganisme berbahaya dapat mulai tumbuh yang menyebabkan produk menjadi beracun. Penyimpanan dengan menggunakan tiga suhu yang berbeda pada dua formula minuman ini tidak banyak mempengaruhi nilai $a_{w}$. Pada Tabel 2 dan Tabel 3 disajikan water activity formula T1 dan formula T2 minuman fungsional Discodoris sp.

Nilai $a_{w}$ pada dua formula minuman ini yang berkisar 0,44 sampai 0,60 tidak berpengaruh terhadap mutu produk selama penyimpanan karena bahan pangan yang mempunyai $a_{w} \quad 0,70$ sudah dianggap cukup baik dan tahan selama penyimpanan.

\section{Penentuan umur simpan}

Menurut Institute of Food Technology (IFT) umur simpan produk pangan adalah selang waktu antara saat produksi hingga saat konsumsi sehingga produk berada dalam kondisi yang memuaskan pada sifat penampakan, rasa, aroma, tekstur dan nilai gizi (Arpah dan Syarief 2000). Menurut Arpah (2007), umur simpan adalah waktu hingga produk mengalami suatu tingkat degradasi mutu tertentu sehingga tidak layak dikonsumsi atau tidak lagi sesuai dengan kriteria yang tertera pada kemasannya (mutu tidak sesuai lagi dengan tingkatan mutu yang dijanjikan, akibat rekasi deteriorasi yang berlangsung.

Berdasarkan data perubahan nilai $a_{w}$ selama penyimpanan dapat dibuat grafik dan persamaan exponensial, karena model yang digunakan adalah ordo satu. Grafik perubahan nilai $a_{w}$ suhu penyimpanan $30^{\circ} \mathrm{C}, 35^{\circ} \mathrm{C}$ dan 45 ${ }^{\circ} \mathrm{C}$ dapat disajikan pada Gambar 1 dan 2. Dengan memplotkan kebalikan suhu mulak (1/T) terhadap In $\mathrm{k}$ (Tabel 4 dan Tabel 5), maka didapatkan grafik yang disajikan pada Gambar 3 dan 4. 


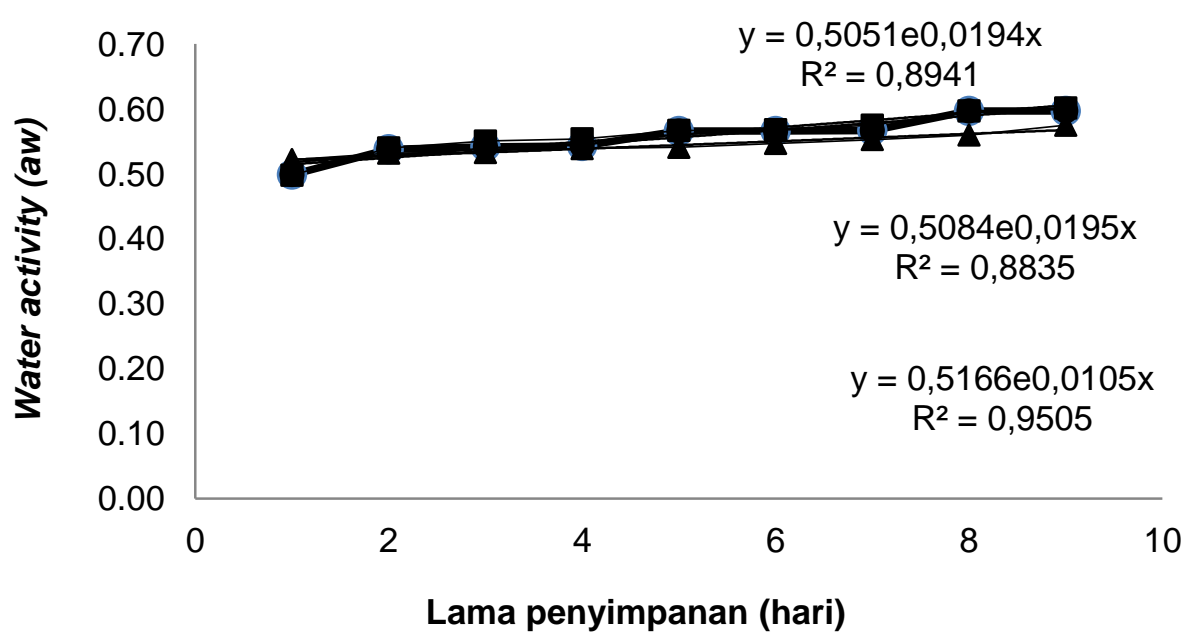

Gambar 1. Laju peningkatan nilai water activity $\left(\mathrm{a}_{\mathrm{w}}\right)$ pada serbuk minuman fungsional lintah laut (Discodoris sp) formula $\mathrm{T} 1$ selama penyimpanan suhu $30{ }^{\circ} \mathrm{C}(\bullet)$, suhu $35^{\circ} \mathrm{C}(\mathbf{\square})$ dan suhu $45^{\circ} \mathrm{C}(\boldsymbol{\Delta})$.

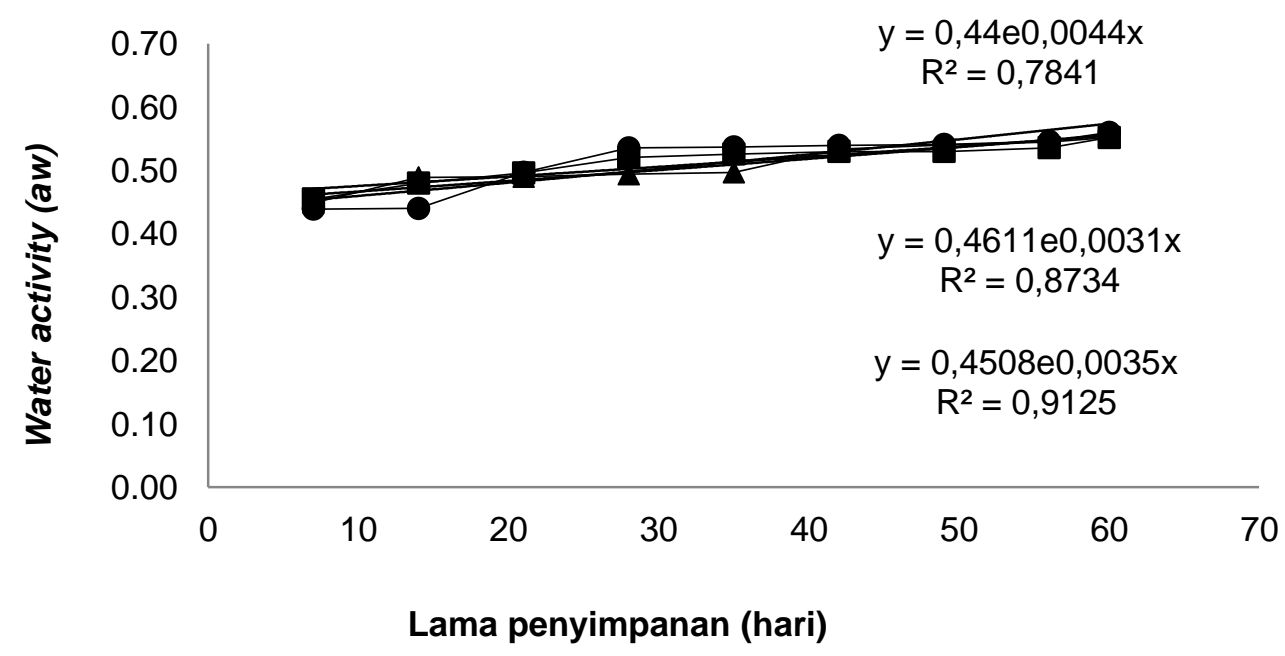

Gambar 2. Laju peningkatan nilai water activity $\left(\mathrm{a}_{\mathrm{w}}\right)$ pada serbuk minuman fungsional lintah laut (Discodoris sp.) formula T2 selama penyimpanan suhu $30^{\circ} \mathrm{C}(\bullet)$, suhu $35^{\circ} \mathrm{C}(\mathbf{-})$ dan suhu $45^{\circ} \mathrm{C}(\boldsymbol{\Delta})$.

Gambar 3 dan 4 merupakan penggabungan linear dari tiga suhu yang digunakan pada penyimpanan serbuk minuman fungsional lintah laut. Persamaan $\mathrm{y}=4223,2-17,789$ dan $\mathrm{y}=$ 1119 -9,2343 merupakan model utama yang akan ditransformasikan kedalam model Arrhenius menjadi Ink= 17,7894223,2 (1/T) dan Ink = 9,2343 - 1119 $(1 / T)$. Nilai $k$ umumnya tidak dapat diperoleh jika kriteria kadaluwarsa ditentukan yang digunakan berdasarkan perubahan sifat fisik (seperti persamaan Labuza maupun berdasarkan perubahan mutu organoleptik), maka pada metode digunakan hubungan langsung antara umur simpan yang diperoleh dengan temperatur 


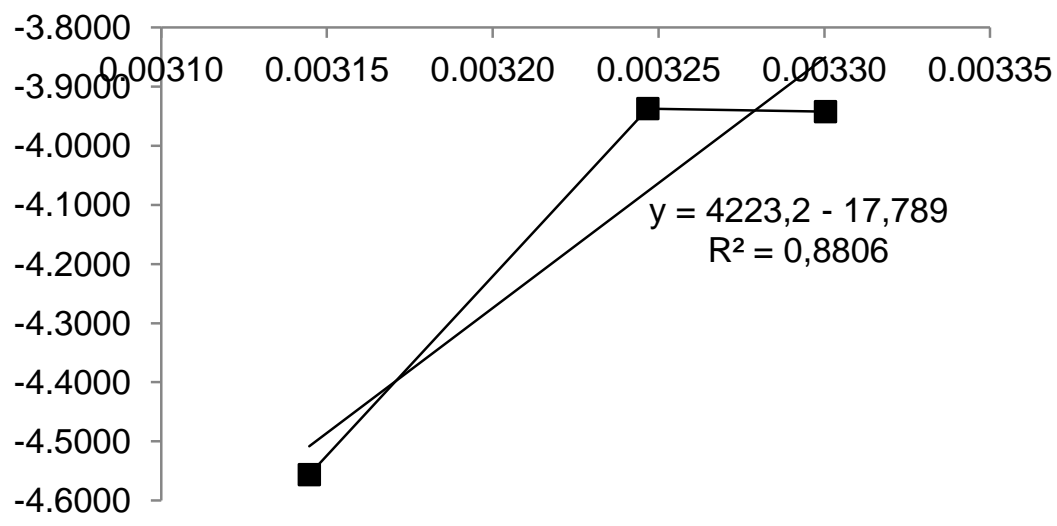

Gambar 3 Persamaan laju kinetik pendugaan umur simpan serbuk minuman fungsional formula T1. 1/T(घ), linear (1/T) (-).

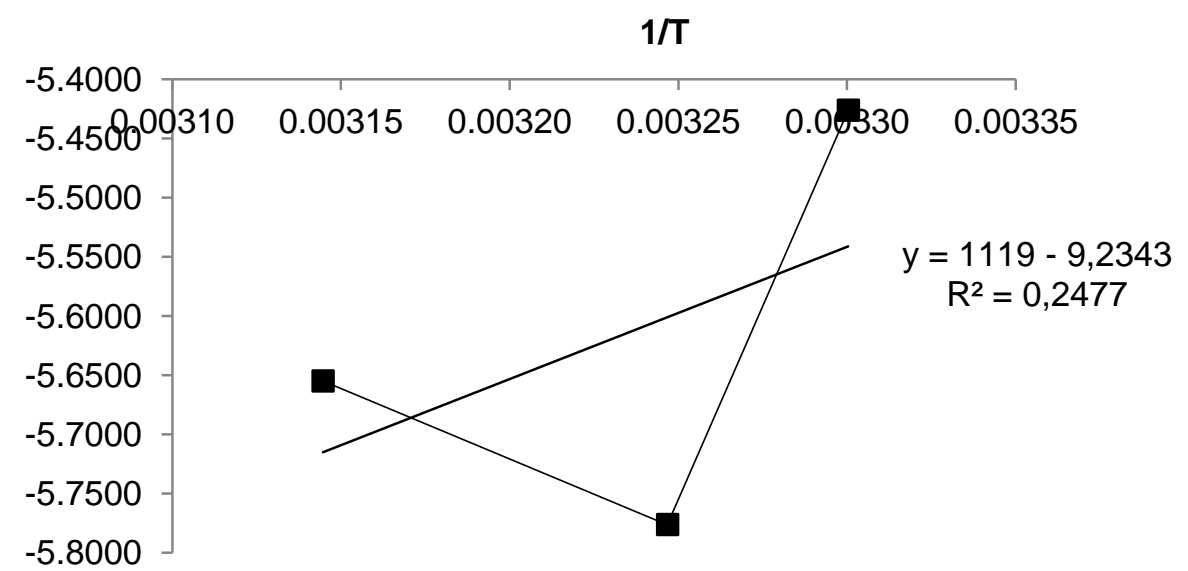

Gambar 4 Persamaan laju kinetik pendugaan umur simpan serbuk minuman

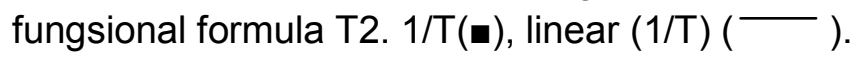

Sedangkan nilai $\mathrm{k}$ yang diperoleh dalam pendugaan ini dihubungkan dengan temperatur menggunakan persamaan Arrhenius:

$$
k=K o e^{-(E a / R T)}
$$

atau dalam bentuk logaritmanya

$$
\ln \mathrm{k}=\ln \mathrm{Ko}-\left(\frac{E a}{R}\right) \frac{1}{T}
$$

Grafik dari Hubungan (In k) sebagai ordinat y dengan $(1 / T)$ sebagai absis $\mathrm{x}$, akan memberikan persamaan garis lurus seperti $y=a+b x$. Dimana slope atau b akan sama dengan (Ea/RT) dan intersept atau a akan sama dengan $=$ In ko. Berdasarkan Gambar 26 dan 27 diperoleh garis lurus dan koefisien korelasi sebagai berikut :

$$
\begin{array}{ll}
\mathrm{Y} & =4223,2 \mathrm{x}-17,789 \\
\mathrm{R}^{2} & =0,8806 \\
\mathrm{ln} \mathrm{k} & =-17,789+4223,2(1 / \mathrm{T}) \\
\mathrm{y} & =1119 \mathrm{x}-9,2343 \\
\mathrm{R}^{2} & =0,2477 \\
\text { Lnk } & =-9,2343+1119(1 / \mathrm{T})
\end{array}
$$


Pada Tabel 4 dan 5 disajikan umur simpan serbuk minuman fungsional Discodoris sp jika diasumsikan suhu selama distribusi dan penyimpanan yaitu suhu $30^{\circ} \mathrm{C}, 35^{\circ} \mathrm{C}$, dan suhu 45 ${ }^{\circ} \mathrm{C}$. Pendugaan umur simpan menggunakan ordo satu karena parameter aktivitas air akan mengalami kenaikan selama penyimpanan. Umur simpan minuman serbuk fungsional dengan formula T2 berkisar antara 3-4 bulan sedangkan umur simpan minuman dengan formula T1 hanya sampai satu bulan lebih.

Hal ini disebabkan karena sampai akhir penyimpanan nilai $a_{w}$ serbuk minuman fungsional formula T2 berkisar 0,55-0,56 sedangkan untuk nilai $a_{w}$ pada minuman serbuk fungsional formula T1 berkisar 0,580,60 . Secara keseluruhan umur simpan minuman serbuk formula T2 lebih tahan lama umur simpannya bila dibandingkan dengan minuman serbuk formula T1.

Faktor yang menyebabkan penurunan umur masa simpan produk adalah peningkatan aktivitas air selama penyimpanan. Aw (activity water) atau aktivitas air adalah jumlah air bebas yang tersedia dan dapat digunakan untuk pertumbuhan mikroba dalam makanan, dimana setiap mikroorganisme membutuhkan jumlah air yang berbeda untuk pertumbuhannya (Danarsi dan Noer 2016).

Semakin rendah nilai $a_{w}$ maka umur simpan produk akan semakin lama karena apabila nilai $a_{w}$ turun maka, ketersediaan kandungan air untuk mikroorganisme akan berkurang sehingga perkembangbiakannya akan terhambat. Nilai $a_{w}$ rendah mampu menurunkan kecepatan pertumbuhan mikroorganisme karena fase lag pertumbuhan dapat diperpanjang serta dapat menurunkan sintesa sel (Jay 2000).

\section{KESIMPULAN}

Pendugaan umur simpan berdasarkan parameter kritis yaitu nilai $\mathrm{a}_{\mathrm{w}}$ (water activity) maka dapat diketahui umur simpan dari formula T1 yaitu selama 16 hari pada suhu $30^{\circ} \mathrm{C}, 20$ hari pada suhu $35^{\circ} \mathrm{C}$ dan 31 hari pada suhu $45^{\circ} \mathrm{C}$, sedangkan untuk formula T2 lebih tahan lama umur simpannya selama 118 hari pada suhu $30^{\circ} \mathrm{C}, 125$ hari pada suhu $35{ }^{\circ} \mathrm{C}$ dan 141 hari pada suhu $45{ }^{\circ} \mathrm{C}$. Umur simpan minuman serbuk formula T2 lebih awet bila dibandingkan dengan formula serbuk minuman $\mathrm{T} 1$.

\section{DAFTAR PUSTAKA}

Arpah M, Syarief R. 2000. Evaluasi model-model pendugaan umur simpan pangan dari difusi hukum fick unidireksional. Buletin Teknologi dan Industri Pangan (11)1:11-16.

Arpah. 2001. Penentuan Kadaluwarsa Produk Pangan. Departemen Teknologi Pangan dan Gizi. Fakultas Teknologi Pertanian. Institut Pertanian Bogor: Bogor.

Arpah. 2007. Penetapan Kadaluarsa Pangan. Departemen Teknologi Pangan dan Gizi. Fakultas Teknologi Pertanian. Institut Pertanian Bogor: Bogor.

Barbosa-Cánovas GV, Anthony JF, Shelly JS, Labuza TP. 2007. Water Activity in Foods, Fundamentals and Applications. IFT Press: USA. 
Buckle KA, Edwards RA, Fleet $\mathrm{GH}$, Wootton M. 1987. IImu Pangan. Purnomo $\mathrm{H}$, Adiono, penerjemah; UI Press: Jakarta.

Danarsi CS, Noer ER. 2016. Pengaruh penyimpanan terhadap mutu mikrobiologi makanan pendamping air susu ibu (MP-ASI) bubur instan dengan subsitusi tepung ikan gabus dan tepung labu kuning. Journal of Nutrition College 5(2): 58-63.

Floros, J.D and V. Gnanasekharan. 1993. Shelf life prediction of packaged foods: chemichal, biological, physical and nutritional aspects. G. Chlaralambous (Ed). Elsevier Publ.,London.

Hasany MR, Afrianto A, Pratama RI. 2017. Pendugaan umur simpan menggunakan metode Accelerated Shelf Life Test (ASLT) model arrhenius pada fruit nori. Jurnal Perikanan dan IImu Kelautan 8(1): 48-55.

Herawati H. 2008. Penentuan umur simpan pada produk pangan. Jurnal Litbang 27(4): 124-130.
Jay JM. 2000. Modern Food Microbiology. Edisi keenam. Aspen Publisher Inc: Maryland.

Labuza TP. 1982. Shelf Life Dating of Foods. Food and Nutrition Press Inc, Connecticut: Westport.

Putri RMS, Nurjanah, Tarman K. 2013. Sinergis taurin lintah laut (Discodoris sp.) dan temulawak (Xanthorriza Roxb.) dalam serbuk minuman Fungsional. Jurnal Pengolahan Hasil Perikanan Indonesia 16(1):48-57.

Rahayu WP, Nababan H, Budijanto S, Syah D. 2003. Pengemasan, Penyimpanan dan Pelabelan. Badan Pengawasan Obat dan Makanan: Jakarta.

Shi J, Lamin SK, Yukio K. 2007. Supercritical fluid technology for extraction of bioactive components. dalam: Shi J, editor. Functional Food Ingredients and Nutraceuticals: Processing Technologies. CRC Press: London. 